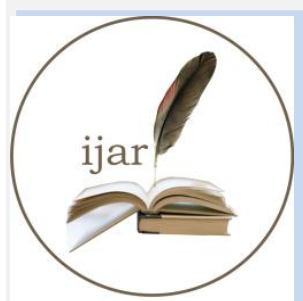

ISSN NO. 2320-5407
Journal Homepage: - www.journalijar.com INTERNATIONAL JOURNAL OF ADVANCED RESEARCH (IJAR)

Article DOI: $10.21474 /$ IJAR01/1415

DOI URL: http://dx.doi.org/10.21474/IJAR01/1415
INTERNATIONAL JOURNAL OF ADVANCED RESEARCH (JJARI

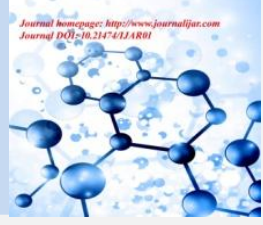

RESEARCH ARTICLE

\title{
WASTELAND AND FOREST IN SOUTH-EAST DRY AGRO-CLIMATIC ZONES OF KARNATAKA USING REMOTE SENSING AND GIS TECHNIQUES.
}

Jagadeesha Menappa Kattimani* and T.J.Renuka Prasad.

Research Scholar and Professor, Department of Geology, Jnana Bharati Campus, Bangalore University, Bangalore560056.

\section{Manuscript Info}

Manuscript History

Received: 12 June 2016

Final Accepted: 19 July 2016

Published: August 2016

Key words:-

Environment, Remote Sensing,

Wasteland, Barren Rocky Land and GIS.

\section{Abstract}

Forest is important source of biodiversity in the study area forest are spreading all over the area we are comparing to forest with wastelands we know that where the Granitic is present where wasteland is developed overall studying about forest in study area highest forest coming under the kanakapura region, North of Tumkur and southern part of Chitradurga Remote sensing (RS) is an efficient and costeffective means of monitoring landscapes. One of the key challenges in the RS study is to improve the accuracy of classification. The present study aims to propose appropriate the Major identifiable wasteland categories are barren rocky; land with scrub; mining wasteland and salt affected area. The final result specifies each wasteland categories in the study area using GIS technique considering the environmental, biophysical and socio-economic factors.

Copy Right, IJAR, 2016,. All rights reserved.

\section{Introduction:-}

The remote sensing techniques are used to measure the land cover, from which land use can be inferred particularly with ancillary data or priority knowledge. Land use/cover studies are multidisciplinary in nature. In addition, facilitating sustainable management of the land, land cover and use information may be used for planning, monitoring and evaluation of development, industrial activity or reclamation.

Forests play vital role in checking soil erosion, controlling flood, increasing the amount of rainfall and creating favourable conditions in the local climate. That is why forests are an important natural wealth of the country. Forest, which comprises of thick and dense canopy of tall trees, which predominantly remain green throughout the year. These lands are discerned by their red to dark red tone and varying in sizes. Based on the tonal and textural variations, the forests of the Kasaba Hobli were divided into three categories as forest plantation, degraded forest and scrub forest.

Wasteland is a degraded land which is not used for any purpose. The wasteland of the Kasaba Hobli were classified into three categories as Land with scurb, Gullied/Revinous land and Barren Rocky / Stony Barren lands generally result from inherent/imposed disabilities such as by location, environment, chemical and physical properties of the soil or financial or management constraints. These are the areas with exposed soil, sand, rocks and never more than $10 \%$ vegetation cover during any season. 


\section{Methodology:-}

unutilized lands using Survey of India (SoI) topomap of 1:50,000 scale, IRS-LISS-III satellite and Google Earth images through GIS software's with limited Ground Truth Check (GTC). The base map used for morphometric analysis carried out through GIS Mapping using SOI topographical sheet of the area scale of 1:50,000. a change detection map has been generated in ArcGIS 9.3 to assess the major changes and land transformation in the watershed. Area statistics of each land use category have been calculated in square kilometre as well as in percentage.

\section{Location Map:-}

Location of the Study area:-

The study area is forest within the Dry Agro Climatic Region of Karnataka and spreads over in $3294 \mathrm{sqkm}$. It lies between $12^{\circ} 30^{\prime} 0^{\prime \prime}$ and $15^{\circ} 0^{\prime} 0^{\prime \prime}$ latitude and between $75^{\circ} 30^{\prime} 0^{\prime \prime}$ and $78^{\circ} 30^{\prime} 0^{\prime \prime}$ longitude and it encompasses seven districts viz., Bangalore Urban, Bangalore Rural, Ramanagara Tumkur, Kolar, Chikkaballapura, Chitradurga. Total district area is 35214 sqkm and the forest area which is focus of the study is only 9\% (Map 1.1).

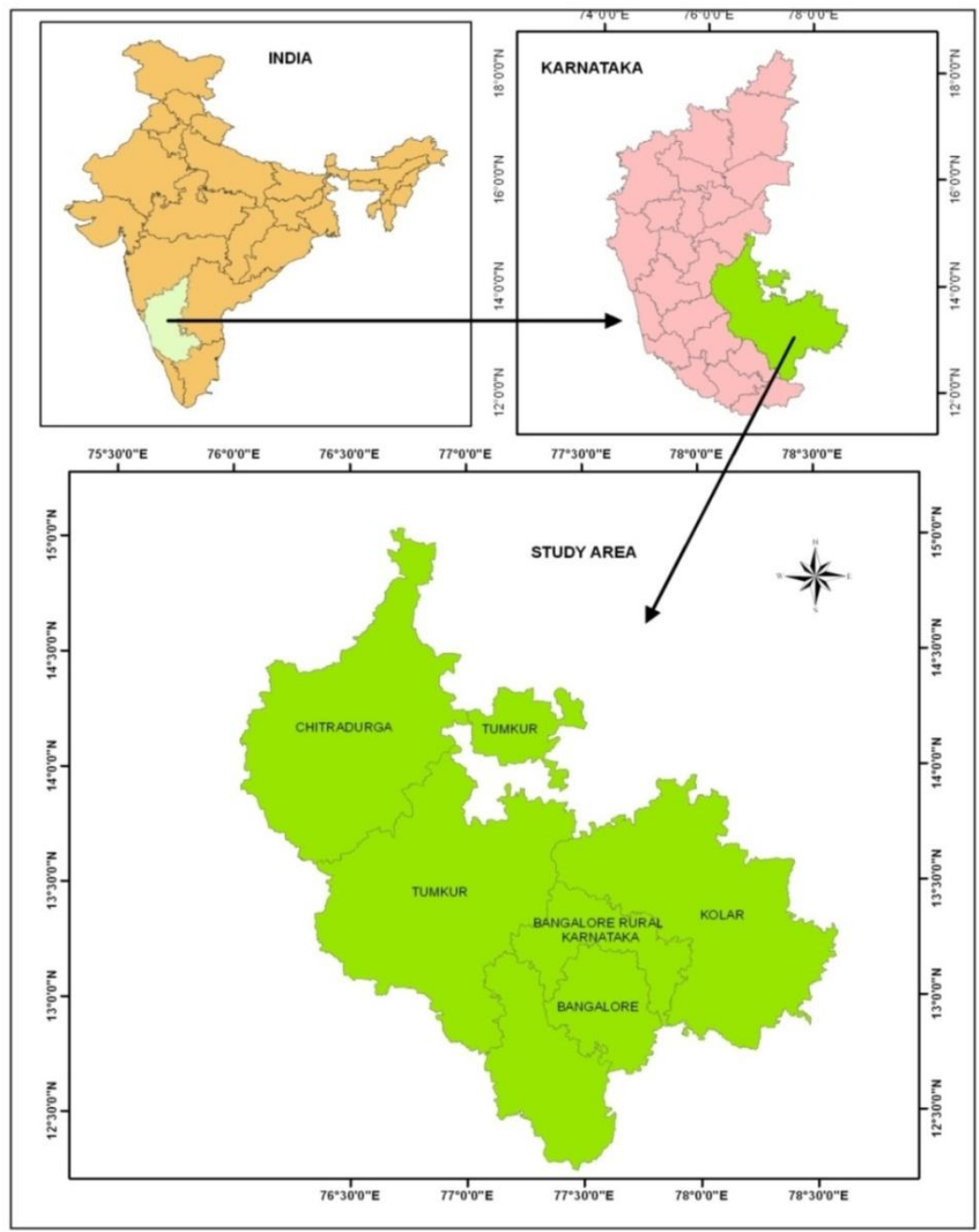

Map 1.1:- Location Map of the study area. 


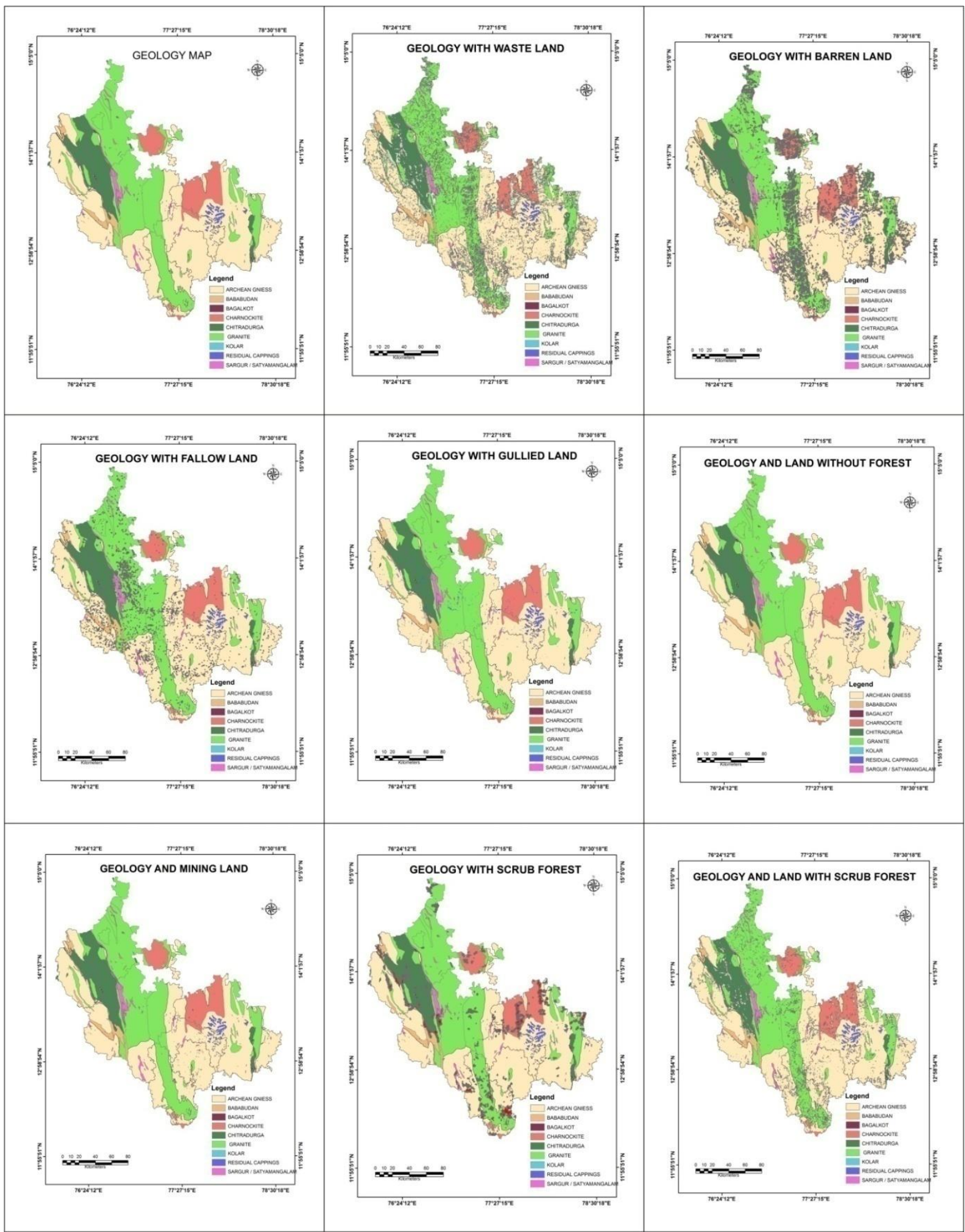

\section{Results:-}

Map 1.2:- Geology with Wasteland Maps.

Forest is important source of biodiversity in the study area forest are spreading all over the area we are comparing to forest with wastelands we know that where the Granitic is present where wasteland is developed overall studying about forest in study area highest forest coming under the kanakapura region, North of Tumkur and southern part of 
Chitradurga remaining the part of the area such as developing cities like Bangalore urban, Bangalore rural are decreasing the forest area because urban developing in and Ramanagar quarry mining is going on so rapidly these are all showing the degrading environment. Tumkur also having the wasteland areas pavagada, Madugiri, Turuvekere, Kunigal and Gubbi part of the areas. Eastern part of the Kolchintamani, Chikkaballapura, Gauribidanur, Mulibagilu, Srinivaspura and chikkaballapura.) north part of the Chitradurga like Challakere, Molakalmuru in these area are having Granite . Eastern-Tumkur to southern part of Ramanagar stretch showing the complete wastelands are formed in these areas small amounts of forests also present but not sufficiently (Map 1.2).

An attempt has been made to compare wasteland in the present study area. There are different types of forest namely Protected forests and Reserved forest. More wastelands cover in the protected forest and less amount in the reserved forest. Reserved forests are part of pavagada, Ramanagar, Bangalore rural and part Kolar area. Protected forest are part of Chitradurga, Tumkur, Ramanagar, Kolar and Bangalore urban. Degradation forest may be due to mining and quarrying thereby created wasteland.

\section{Acknowledgment:-}

Authors are thankful to the Karnataka State Remote Sensing Application Centre (KSASAC) for producing the satellite data for the study area. Author acknowledges the financial assistance under Rajiv Gandhi National Fellowship (RGNF) 2011-15.

\section{References:-}

1. Basavarajappa, H. T., Pushpavathi, K. N., \& Manjunatha, M. C. (2016). Mapping and Reclamation of Wastelands in Yelanduru Taluk of Chamarajanagara District, Karnataka, India Using Geo-Informatics Technique.

2. CGWB., 2008. Central Groundwater Board. Groundwater information booklet, Chamarajanagar District, Karnataka south western region, Bangalore

3. Chilar J (2000) Land cover mapping of large areas from satellites: status and research priorities. Int J Remote Sens 21(67):1093-1114.

4. Kachhwaha TS (1985) Temporal monitoring of forest land for change detection and forest cover mapping through satellite remote sensing. Proc. Sixth Asian Conference on Remote Sensing, Hyderabad: 77-83.

5. Kachhwala, T.S.,. Temporal monitoring of forest land for change detection and forest cover mapping through satellite remote sensing. In the Proceedings of the 6th Asian Conference on Remote sensing, Hyderabad, pp: 7783,1985.

6. Khanday, M. Y., Khan, I., \& Javed, A. (2016). Watershed management on land use/land cover dynamics in semi-arid watershed, Central India. Arabian Journal of Geosciences, 9(6), 1-7.

7. McCracker SD, Brondizio E, Moran EF, Nelson D, Siqueira A, Pedrazar CR (1998) The use of remote sensing and GIS in the collection of survey data on households and land-use.

8. Navalgund, R.R., V. Jayaraman and P.S. Roy, Remote sensing application: An overview. Current Science, 93(12): 1747-1766, 2007.

9. Navalgund, R.R., V. Jayaraman and P.S. Roy, Remote sensing application: An overview. Current Science, 93(12): 1747-1766, 2007.

10. Star JL, Estes JE and McGwire KC, Integration of geographic information systems and remote sensing. New York, NY: Cambridge University Press, 1997.

11. Thakkar, A. K., Desai, V. R., Patel, A., \& Potdar, M. B. (2016). An effective hybrid classification approach using tasseled cap transformation (TCT) for improving classification of land use/land cover (LU/LC) in semiarid region: a case study of Morva-Hadaf watershed, Gujarat, India. Arabian Journal of Geosciences, 9(3), 113. 